\title{
Gusperimus Trihydrochloride
}

National Cancer Institute

\section{Source}

National Cancer Institute. Gusperimus Trihydrochloride. NCI Thesaurus. Code C1598.

A derivative of the antitumor antibiotic spergualin with immunosuppressant activity.

Gusperimus inhibits the interleukin-2-stimulated maturation of T cells to the $S$ and G2/M phases and the polarization of the T cells into IFN-gamma-secreting Th1 effector T cells, resulting in the inhibition of growth of activated naive CD4 T cells; this agent may suppress growth of certain T-cell leukemia cell lines. ( $\mathrm{NCl04)}$ 